\title{
ベンゾイルアセトンで化学修飾されたゲル膜の光分解による $\mathrm{Al}_{2} \mathrm{O}_{3}$ 薄膜のパターニング
}

\author{
趙 高揚・峠 登 \\ 近畿大学理工学部金属工学科, 577 東大阪市小若江 3-4-1
}

\author{
Fine Patterning of $\mathrm{Al}_{2} \mathrm{O}_{3}$ Thin Films by the Photolysis of $\mathrm{Gel}$ \\ Films Chemically Modified with Benzoylacetone \\ Gaoyang ZHAO and Noboru TOHGE \\ Department of Metallurgical Engineering, Kinki University, 3-4-1, Kowakae, Higashi-Osaka-shi, Osaka 577
}

[Received May 24, 1995; Accepted August 24, 1995]

\begin{abstract}
The effects of UV-irradiation on the properties of $\mathrm{Al}_{2} \mathrm{O}_{3}$ gel films obtained from $\mathrm{Al}(\mathrm{O}-\mathrm{sec} \text { - } \mathrm{Bu})_{3}$ chemically modified with benzoylacetone have been studied. These gel films showed an optical absorption band at around $325 \mathrm{~nm}$ characteristic of the $\pi-\pi^{*}$ transition in the chelate ring. The irradiation of UV-light of $365 \mathrm{~nm}$ on the gel films dissociated the chelate ring and simultaneously decreased the solubility of the gel films in acetone solutions containing $\mathrm{HNO}_{3}$. This finding was successfully applied to the fine patterning of $\mathrm{Al}_{2} \mathrm{O}_{3}$ films. The gel films were irradiated with UV-light and then leached in $\mathrm{HNO}_{3}$-acetone solutions, followed by the heat treatment at $400^{\circ} \mathrm{C}$ to form finely patterned $\mathrm{Al}_{2} \mathrm{O}_{3}$ films on a variety of substrates.
\end{abstract}

Key-words : Sol-gel process, Chemical modification, Photolysis, Fine patterning, $\mathrm{Al}_{2} \mathrm{O}_{3}$, Thin films.

\section{1. 緒 言}

ゾル-ゲル法は酸化物薄膜を得るうえで非常に有用な手 法である.しかし, ゾルーゲル法に扔いて出発原料として 一般に用いられる金属アルコキシドの多くは，水に対する 反応性が高く, コーティングのための均一なゾルを得るの が困難である.この欠点を克服するための一つの方法とし て化学修飾法が盛んに研究されている1) 5). 金属アルコ キシドを溶媒中で $\beta$-ジケトンとを反応させると, アルコ キシル基の一部が $\beta$-ジケトナトで置換され, 加水分解に 対して安定なキレート環が形成される.このように反応性 の高い金属アルコキシドを化学修飾すると, 加水分解 · 重 縮合反応が抑制されるため, ゾル-ゲル法による薄膜の作 製を大気中で行うことができるようになる，これまで，化 学修飾法により種々の薄膜が作製されている2,6),7).

一方, 著者らは最近, $\beta$-ジケトンで化学修飾した金属ア ルコキシドから得られるゲル膜に紫外線を照射すると, キ レート環が分解され, それと同時にアルコールあるいは酸 性水溶液に対するゲル膜の溶解性が変化することを見いだ し，この現象を利用した薄膜の新しい微細パターニング技 術を開発した8) 10).このようなゲル膜の光分解を利用し た微細パターニング技術では, スタンパーを用いる方
法11) 14) とは異なり, 光学用のみならず電子素子用酸化物 薄膜もパターニングすることができる．この方法による $\mathrm{ZrO}_{2}, \mathrm{TiO}_{2}$ 薄膜などの微細パターニングについては既に 報告したが8),9), $\mathrm{Al}_{2} \mathrm{O}_{3}$ 薄膜の微細パターニングについては 十分検討されていなかった ${ }^{10)}$ ，それは，Al-アルコキシド の化学修飾剂として最も適しているアセ卜酢酸エチル EAc$\mathrm{AcH}$ を用いた場合，得られるゲル膜はキレート環の $\pi-\pi^{*}$ 遷移による吸収バンドを $270 \mathrm{~nm}$ 付近に有し, 高圧水銀灯 では励起効率が悪いためである10)。しかし，ベンゾイル アセトン BzAcH を修飾剤として用いると, 金属アルコキ シドに対する安定化能は高くないが，キレート環による吸 収バンドは長波長側にシフトし, 高圧水銀灯による励起効 率の向上が期待される8).

本研究では, ベンゾイルアセトン $\mathrm{BzAcH}$ で化学修飾さ れた $\mathrm{Al}(\mathrm{O}-\mathrm{sec}-\mathrm{Bu})_{3}$ から得られる $\mathrm{Al}_{2} \mathrm{O}_{3}$ ゲル膜について, 光吸収スペクトル及び溶解性に対する紫外線の照射効果を 調べ, $\mathrm{Al}_{2} \mathrm{O}_{3}$ 薄膜の微細パターニングの可能性を検討し た. 更に, 紫外線の照射効果と比較するために, 光吸収ス ペクトルに対する熱処理の効果も検討した.

\section{2. 実験方法}

化学修飾された金属アルコキシドからの $\mathrm{Al}_{2} \mathrm{O}_{3}$ ゲル膜 の作製手順を図 1 に示す。コーティング溶液の作製には, 出発原料としてアルミニウムトリ-sec-ブトキシド $\mathrm{Al}(\mathrm{O}-$ $s e c-\mathrm{Bu})_{3}$ (関東化学製) と化学修飾剂にベンゾイルアセト ソ $\mathrm{C}_{6} \mathrm{H}_{5} \mathrm{COCH}_{2} \mathrm{COCH}_{3}$ (和光純薬工業製) $\mathrm{BcAcH}$ を用い,

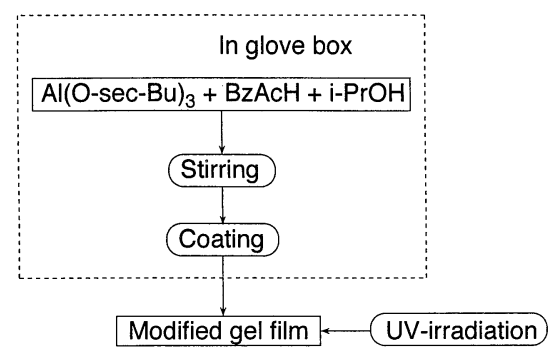

Fig. 1. Preparation procedure of $\mathrm{Al}_{2} \mathrm{O}_{3}$ gel films from $\mathrm{Al}$ $(\mathrm{O}-\mathrm{sec}-\mathrm{Bu})_{3}$ modified with $\mathrm{BzAcH}$. 
溶媒にはイソプロピルアルコール $i \mathrm{PrOH}$ (和光純薬工業 製）を用いた。 $i$ - $\mathrm{PrOH}$ で希釈した $\mathrm{Al}(\mathrm{O}-\mathrm{sec}-\mathrm{Bu})_{3}$ に $\mathrm{BzAcH}$ を加えて室温で 3 時間かくはんし，十分に反応さ せた． $i$ - PrOH 溶媒中では化学修飾剤 $\mathrm{BzAcH}$ の溶解度が 低いために, 本研究では $\mathrm{Al}(\mathrm{O}-\mathrm{sec}-\mathrm{Bu})_{3}$ と $\mathrm{BzAcH}$ のモル 比は $2: 1$ とした. 得られた溶液を用いて, ディッピング 法により各種の基板にコーティングを行った. 基板として は，UV-可視吸収スペクトルの測定には石英ガラスを， 微細パターンの作製にはソーダ石灰ガラスと $\mathrm{Si}$ ウエハー を用いた．先に述べたように, $\mathrm{BzAcH}$ の $\mathrm{Al}(\mathrm{O}-\mathrm{sec}-\mathrm{Bu})_{3}$ に対する安定化能は高くないため, 化学修飾された金属ア ルコキシドを積極的に加水分解しなかっただけではなく， コーティング溶液の調製からコーティングまでのすべての 操作を, 相対湿度30\%以下のグローブボックス中で行っ た.

コーティングしたゲル膜を $50^{\circ} \mathrm{C} て ゙ ~ 1 \mathrm{~h}$ 乾燥した後, 大気 中で紫外線照射を行った. 紫外線照射用の光源には高圧水 銀灯（ウシオ電機製，UIS-25102，250 W）を用い, 硫酸 銅水溶液フィルター $\left(\mathrm{CuSO}_{4} \cdot 5 \mathrm{H}_{2} \mathrm{O} 100 \mathrm{~g} / \mathrm{l}\right)$ と色ガラス （東芝硝子製, UV-D33S）を通して, 波長 $365 \mathrm{~nm}$ 付近の 紫外線を照射した．紫外線照射と比較するためのゲル膜の 熱処理は, 大気中 $200^{\circ} \mathrm{C} て ゙$ 行った. ゲル膜の光吸収スペク トルは分光光度計（島津製作所製, UV-2100PC) で, 膜 厚は表面粗さ計 (小坂研究所製, SE-2300) で測定した. また，条件を変化させたときのパターニング特性は，表面 粗さ計及び電子顕微鏡を用いて検討した。

\section{3. 結果及び考察}

\section{1 光吸収スペクトルの変化}

$\mathrm{Al}(\mathrm{O}-\mathrm{sec}-\mathrm{Bu})_{3}$ を $i-\mathrm{PrOH}$ 中で $\mathrm{BzAcH}$ と反応させると, 次式のようにアルコキシル基の一部が BzAc で置換され, キレート環が形成される2)

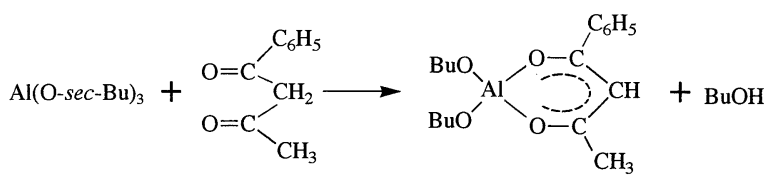

このように化学修飾された金属アルコキシドから得られ た $\mathrm{Al}_{2} \mathrm{O}_{3}$ ゲル膜の光吸収スペクトルと，このゲル膜に 365 $\mathrm{nm}$ 付近の紫外線を照射したときのスペクトルの変化を 図 2 に示す．図から明らかなように，乾燥したゲル膜は $325 \mathrm{~nm}$ と $250 \mathrm{~nm}$ 付近にそれぞれ吸収バンドを有する. $325 \mathrm{~nm}$ 付近の吸収バンドは $\mathrm{Al}_{2} \mathrm{O}_{3} / \mathrm{BzAc}$ 系ゲル膜中のキ レート環の $\pi-\pi$ 遷移に起因する。この吸収バンドは, $\mathrm{BzAcH}$ 自身の吸収バンド $(310 \mathrm{~nm})$ と比べても長波長側 に15 nm シフトしており ${ }^{8)}, \mathrm{BzAcH}$ はゲル膜中でもキ レート環を形成したあまであることを示している．更に $\mathrm{EAcAcH}$ で修飾した場合10) と比較すると，フェニル基の 電子吸引効果により約 $55 \mathrm{~nm}$ 長波長側に位置している. $325 \mathrm{~nm}$ 付近の吸収バンドの強度は, 紫外線の照射時間と ともに徐々に減少し， $12 \mathrm{~min}$ 程度の照射で吸収バンドが

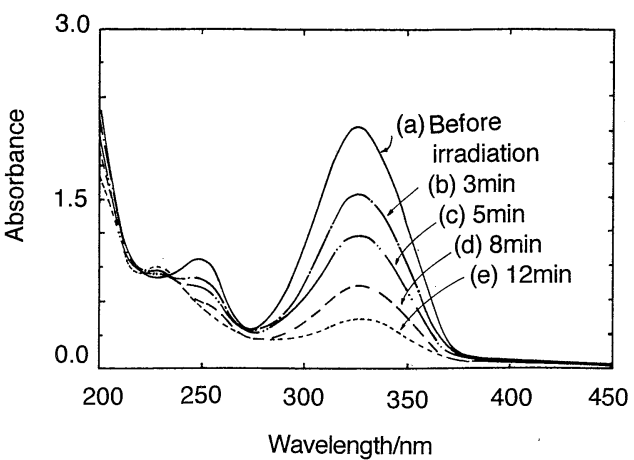

Fig. 2. Change in optical absorption spectra with UV-irradiation $(365 \mathrm{~nm})$ for $\mathrm{Al}_{2} \mathrm{O}_{3}$ gel films modified with $\mathrm{BzAcH}$.

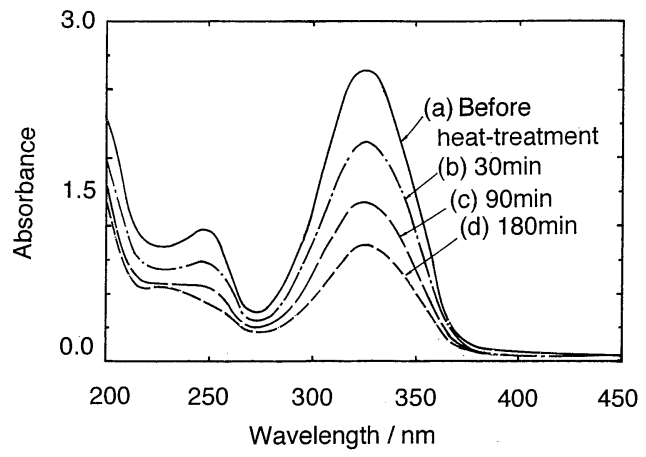

Fig. 3. Change in optical absorption spectra with heat treatment at $200^{\circ} \mathrm{C}$ for $\mathrm{Al}_{2} \mathrm{O}_{3}$ gel films modified with $\mathrm{BzAcH}$.

ほほ完全に消失する。これは，紫外線照射によってキレー 卜環が分解されていることを示している。一方， $250 \mathrm{~nm}$ 付近の吸収バンドは $\mathrm{BzAcH}$ のフェニル基による吸収であ る15)。紫外線照射によって，この吸収バンドの強度も減 少するが, $230 \mathrm{~nm}$ 付近に新しい吸収バンドが現れる。こ のような吸収バンドの変化に対応する構造変化の詳細はま だ明確ではないが，紫外線照射によってフェニル基は分解 せず，フェニル基の結合状態が変化するためと考えられ る.

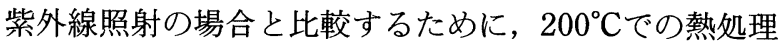
による光吸収スペクトルの変化を図 3 に示す. $325 \mathrm{~nm}$ 付 近の吸収バンドの変化の様子は紫外線照射の場合と大体同 じであるが，その速度は紫外線照射の場合よりかなり遅 い. 一方, $250 \mathrm{~nm}$ 付近の吸収バンドの変化は紫外線照射 の場合と異なる. 熱処理の場合, この吸収バンドの強度は $325 \mathrm{~nm}$ 付近の吸収バンドと同様に一様に減少する。これ は熱処理によってフェニル基も分解されることを示唆して いる. したがって, 紫外線照射でも熱処理でもゲル膜中の キレート環は同じように分解されるが，その分解過程の細 部は少し異なっていると考えられる.

図 4 に, $325 \mathrm{~nm}$ に抢ける吸光度の対数値を紫外線の照 射時間あるいは熱処理時間の関数として示す. 図より，吸 光度の対数值は, いずれの場合も時間に対してほほ直線的 に減少することが分かる．この結果は，紫外線照射及び熱 処理による $\pi-\pi$ 遷移バンドの消失，すなわちキレート環 


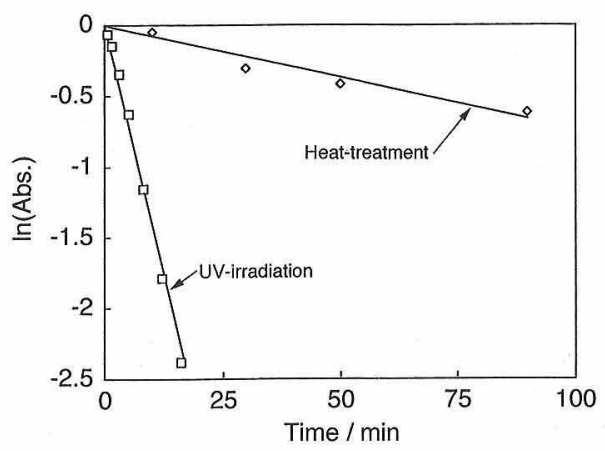

Fig. 4. Intensity of the optical absorption band at $325 \mathrm{~nm}$ as a function of irradiation time of UV-light or heat treatment time for $\mathrm{Al}_{2} \mathrm{O}_{3}$ gel films.

の分解が，いずれの場合も膜中に残存するキレート環の濃 度に一次的に依存することを示している。しかし，紫外線 照射の場合の分解速度は $200^{\circ} \mathrm{C} に$ 括ける熱処理より 18 倍程 度速い。これは，BzAcのキレート環の分解に対して紫外 線照射が効果的であることを示している．更に，化学修飾 剂として BzAcH を用いることにより，高圧水銀灯による $\pi ー \pi$ 遷移の励起を効率的に行うことがでさるようになっ たといえる.

\section{2 紫外線照射による溶解性の変化}

$\mathrm{Al}_{2} \mathrm{O}_{3} / \mathrm{BzAc}$ 系ゲル膜に紫外線を照射すると, 光吸収久 ペクトルたけでなく，特定の有機溶媒に対するゲル膜の溶 解性も変化した. 図 5 に, ゲル膜の溶解性に対する紫外線 照射の影響を調べるための実験手順を示す。まず，くし形 の金属製マスクを通して $\mathrm{Al}_{2} \mathrm{O}_{3} / \mathrm{BzAc}$ ゲル膜に紫外線を照 射し(a), 次に，種々の溶液中でリーチングを行った．今 回のゲル膜では，リーチング液にアセトンを用いると，紫 外線を照射した部分は溶解せずに残っているが，未照射部 分は完全に溶解することを見いだした (b).

紫外線照射によってゲル膜の溶解性が変化することは, $\mathrm{ZrO}_{2} / \mathrm{AcAc}$ 系や $\mathrm{TiO}_{2} / \mathrm{BzAc}$ 系でも既に見いたしてい る8) 10). しかし，修飾剤として同じ BzAcH を用いても， 今回の $\mathrm{Al}_{2} \mathrm{O}_{3} / \mathrm{BzAc}$ 系ゲル膜の溶解挙動は $\mathrm{TiO}_{2} / \mathrm{BzAc}$ 系 とは少し異なっている。未照射の $\mathrm{TiO}_{2} / \mathrm{BzAc}$ 系ゲル膜

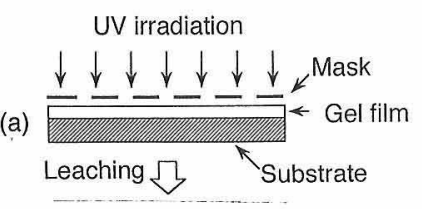

(b)

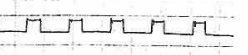
\Heat treatment

(c)

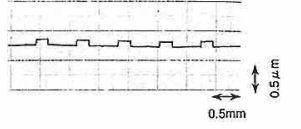

Fig. 5. Experimental procedure to demonstrate the effect of UV-irradiation on the solubility of modified gel films.

(a) UV-irradiation, (b) line profile of leached gel film and (c) line profile of heat-treated $\mathrm{Al}_{2} \mathrm{O}_{3}$ films.
は，イソプロピルアルコールのようなアルコール系の溶媒 に溶解するが，紫外線照射によって不溶化した8),10)。一 方, 今回の $\mathrm{Al}_{2} \mathrm{O}_{3} / \mathrm{BzAc}$ 系ゲル膜の場合は, イソプロピル アルコール, メタノール，あるいはエタノールのようなア ルコール系の溶媒には紫外線照射の有無にかかわらず溶解 せず，アセトンを用いたときに照射部と未照射部で溶解性 に差が見られた。これは， $\mathrm{Al}_{2} \mathrm{O}_{3} / \mathrm{BzAc}$ 系と $\mathrm{TiO}_{2} / \mathrm{BzAc}$ 系ゲル膜の構造の違いを示しているものと考えられる.

更に, $\mathrm{Al}_{2} \mathrm{O}_{3} / \mathrm{BzAc}$ 系ゲル膜をリーチングする場合，ア セトンに少量の硝酸を加えるとリーチング速度を加速でき ることを見いだした。厚さ約 $0.25 \mu \mathrm{m}$ のゲル膜において， 紫外線の未照射部分を完全に溶解するためには, アセトン のみの場合は30 min 程度を要したが， 1.2 vol\%の硝酸を

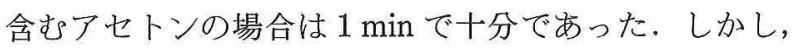
同じ硝酸を含むリーチング液に対して，40 min 紫外線を 照射したゲル膜を完全に溶解させるためには $3.5 \mathrm{~h}$ 必要で めり，紫外線を照射したゲル膜は高い耐酸性を示した。紫 外線照射によってアセトン溶液に対する $\mathrm{Al}_{2} \mathrm{O}_{3} / \mathrm{BzAc}$ 系ゲ ル膜の溶解度が変化することは, 紫外線照射でゲル膜の構 造が大きく変化することを示唆している.

図 5 に括いて，リーチング後に残留するゲル膜の厚さ は約 $0.25 \mu \mathrm{m}$ である(b).このゲル膜を大気中, $400^{\circ} \mathrm{C} て ゙$ $20 \mathrm{~min}$ 熱処理すると, 厚さが約 $0.1 \mu \mathrm{m}$ となった(c).こ のような熱処理による比較的大きな膜厚の減少は, 残存有 機物の消失と緻密化のためである.

\section{$3.3 \mathrm{Al}_{2} \mathrm{O}_{3}$ 薄膜のパターニング}

紫外線照射による $\mathrm{Al}_{2} \mathrm{O}_{3} / \mathrm{BzAc}$ ゲル膜の硝酸ーアセトン 溶液に対する溶解度の変化を利用して, 微細パターニング を行った。そのプロセスは，基本的には図 5 に示した手

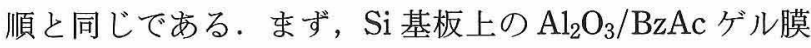
に，より微細なパターンを有するガラス製のマスクを通し て紫外線を $40 \mathrm{~min}$ 照射した．次に，1.2 vol\%の硝酸を含 むアセトン中で 1 min リーチングを行った。このように してパターニングされたゲル膜の走査型電子顕微鏡 (SEM) 写真を図 6 に示す. 写真から明らかなように，幅 約 $10 \mu \mathrm{m}$, 間隔約 $5 \mu \mathrm{m}$ の長方形の $\mathrm{Al}_{2} \mathrm{O}_{3}$ のパターンが形 成されている。これは，使用したマスクのネガパターンと

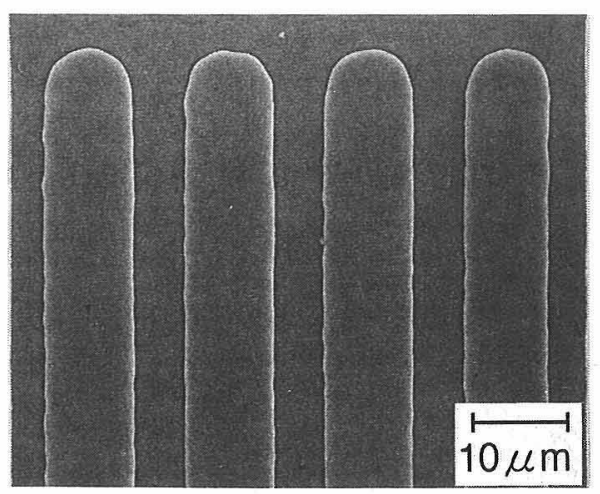

Fig. 6. SEM photograph of patterned $\mathrm{Al}_{2} \mathrm{O}_{3}$ film on $\mathrm{Si}$ substrate. The bar in the photograph shows $10 \mu \mathrm{m}$. 
なっている. このゲル膜を $400^{\circ} \mathrm{C} て ゙ 20 \min$ 熱処理すること により残留有機物が分解され，パターニングされた $\mathrm{Al}_{2} \mathrm{O}_{3}$ 薄膜が得られた. 同じようにして, ソーダ石灰ガラス基板 にも $\mathrm{Al}_{2} \mathrm{O}_{3}$ の微細パターンを形成することができた.上 記の熱処理条件で得られる $\mathrm{Al}_{2} \mathrm{O}_{3}$ 薄膜は, $\mathrm{X}$ 線的に非晶 質であった.

以上のように, $\mathrm{BzAcH}$ で化学修飾した Al-アルコキシ ドを出発原料に用いると, 紫外線照射により $\mathrm{Al}_{2} \mathrm{O}_{3}$ 薄膜 をパターニングできることが明らかとなった。

\section{4. 総 括}

$\mathrm{BzAcH}$ で化学修飾した $\mathrm{Al}(\mathrm{O}-\mathrm{sec}-\mathrm{Bu})_{3}$ から得られた $\mathrm{Al}_{2} \mathrm{O}_{3}$ ゲル膜について, 光吸収スペクトルや溶解性に対す る紫外線の照射効果を調べた。更に，これらを基に $\mathrm{Al}_{2} \mathrm{O}_{3}$ 薄膜のパターニングプロセスを検討した結果, 以下のよう な知見を得た。

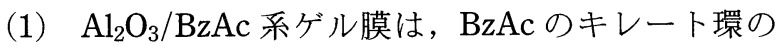
$\pi-\pi$ 遷移に特徵的な吸収バンドを $325 \mathrm{~nm}$ 付近に示した. この吸収バンドは365 nm 付近の紫外線照射によって消失 し，キレート環の分解が示唆された．更に，その分解過程 は一次反応であった.

（2）ゲル膜中のキレート環は， $200^{\circ} \mathrm{C}$ 熱処理によっ ても分解された。しかし，紫外線照射による分解速度は熱 処理よりかなり速く, 光分解の効率の高さが示された.

(3) 紫外線照射によって, $\mathrm{Al}_{2} \mathrm{O}_{3} / \mathrm{BzAc}$ 系ゲル膜のア セトン，あるいは $\mathrm{HNO}_{3}$-アセトン溶液に対する溶解性は 著しく減少した. 更に, この現象を利用すると, $\mathrm{Al}_{2} \mathrm{O}_{3}$ 薄 膜の微細パターニングが可能であることが明らかに
なった.

謝 辞 本研究の一部は, 文部省科学研究費 (No. 05453081), ならびに日本私学振興財団及び近畿大学環境科学研究所の助成金 によって行われたものである.

\section{文献}

1) J. C. Debsikbar, J. Non-Cryst. Solids, 86, 231-40 (1986).

2) H. Uchihashi, N. Tohge and T. Minami, Seramikkusu Ronbunshi, 97, 396-99 (1989).

3) F. Babonneau, L. Coury and J. Livage, J. Non-Cryst. Solids, 121, 153-57 (1990).

4) Y. Abe, T. Gunji, Y. Kimata, M. Kuramata, A. Kaşgöz and T. Misono, J. Non-Cryst. Solids, 121, 21-25 (1990).

5) R. Nass and H. Schmidt, J. Non-Cryst. Solids, 121, 329-33 (1990).

6) N. Tohge, S. Takahashi and T. Minami, J. Am. Ceram. Soc., 74, 67-71 (1991).

7) N. Tohge, E. Fujii and T. Minami, J. Mater. Sci: Mater. Electron., 5, 356-59 (1994).

8) N. Tohge, K. Shinmou and T. Minami, J. Sol-Gel Sci. Technol., 2, 581-85 (1994).

9) N. Tohge, K. Shinmou and T. Minami, Jpn. J. Appl. Phys., 33, 1181-84 (1994).

10) N. Tohge, K. Shinmou and T. Minami, SPIE Proc. Sol-Gel Optics III, 2288, 589-98 (1994).

11) N. Tohge, A. Matsuda, T. Minani, Y. Matsuno, S. Katayama and Y. Ikeda, J. Non-Cryst. Solids, 100, 501-05 (1988).

12) A. Matsuda, Y. Matsuno, S. Kataoka, S. Katayama, T. Tsuno, N. Tohge and T. Minami, SPIE Proc. Sol-Gel Optics, 1328, 62-70, 71-79 (1990).

13) R. L. Roncone, L. A. Weller-Brophy, L. Weisenbach and B. J. J. Zelinski, J. Non-Cryst. Solids, 128, 111-17 (1991).

14) H. Krug, N. Merl and H. Schmidt, J. Non-Cryst. Solids, 147/ 148, 447-50 (1992).

15) P. R. Singh and R. Sahai, J. Indian Chem. Soc., 46, 945-50 (1969). 